\title{
OPAC Design Enhancements and Their Effects on Circulation and Resource Sharing within the Library Consortium Environment Michael J. Bennett
}

A longitudinal study of three discrete online public access catalog (OPAC) design enhancements examined the possible effects such changes may have on circulation and resource sharing within the automated library consortium environment. Statistical comparisons were made of both circulation and interlibrary loan (ILL) figures from the year before enhancement to the year after implementation. Data from sixteen libraries covering a seven-year period were studied in order to determine the degree to which patrons may or may not utilize increasingly broader OPAC ILL options over time. Results indicated that while ILL totals increased significantly after each OPAC enhancement, such gains did not result in significant corresponding changes in total circulation.

M ost previous studies of online public access catalog (OPAC) use and design have centered on transaction-log analysis and user survey results in the academic library environment. Measures of patron success or lack thereof have traditionally been expressed in the form of such concepts as "zero-hit" analysis or the "branching" analysis of Kantor and, later, Ciliberti. ${ }^{1}$ Missing from the majority of the literature on OPAC study, however, are the effects that use and design have had on public library patron borrowing practices.

Major drawbacks to transaction-log analyses and user surveys as a measure of successful OPAC use include a lack of standardization and the inherent difficulties in interpreting resulting data. As Peters notes, "[s]urveys measure users' opinions about online catalogs and their perceptions of their successes or failures when using them, while transaction logs simply record the searches conducted by users. Surveys," he concludes, "measure attitudes, while transaction logs measure a specific form of behavior." ${ }^{2}$ In both cases it is difficult, in many instances, to draw clear conclusions from either method.

Circulation figures, on the other hand, measure a more narrowly defined level of patron success. Circulation is a discrete output that is the direct result of patrons' initiated interaction with one or many library collections, one or many levels of library technology. With the recent advent of such enhanced OPAC functionality as patron-placed holds on items from broader and broader catalogs, online catalogs now more than ever not only serve as search mechanisms but also as ways for patrons to directly

Michael J. Bennett (mbennett@cwmars.org) is Digital Initiatives Librarian, C/W MARS Library Network, Worcester, Massachusetts. obtain materials from multiple sources. It follows that an investigation of the possible effects such enhancements may have on general circulation trends is warranted.

\section{Literature review}

During the mid-to-late 1980s, transaction-log analysis was introduced as an inexpensive and easy method of looking at OPAC use in primarily the academic library environment. Peters's transaction-log survey of more than thirteen thousand searches executed over a fivemonth period at the University of Missouri-Kansas City remains particularly instructive today for its large sample and transferable design as well as its interpretation of results. ${ }^{3}$

Here analysis was broken into two phases. In phase one, usage patterns by search type and failure rates as measured by zero hits were examined as dependent variables with search type as the independent variable in a comparison study. Phase two took this one step further in the assigning of what Peters termed "probable cause" of zero hits. These probable causes fell into patterns that, in turn, resulted in the identification of fourteen discernable error types that included such things as typographical errors and searches for items not in the catalog. Once again, search type formed the independent variable while error type shaped the dependent variable in a simple study of error types as a percentage of total searches.

Peters found that users rarely employed truncation or any advanced feature searches and that failures were due primarily to such consistent erroneous search patterns as typographical errors and misspellings. More importantly, however, he cogently reassessed transaction-log analysis as a tool and critiqued its limitations. Zero hits, for example, need not necessarily construe failure when a patron performs a quality search and finds that the library simply does not own the title in question. Concerning intelligible outputs from transaction-log study, Peters found that, "if the user is seen as carrying on a dialog of sorts with the online catalog, then it could be said that most transaction logs record only half of the conversation. More information about the system's response to the user's queries would help us better understand why patrons do what they do." 4

A look at subsequent transaction-log analyses into the 1990s reveals somewhat differing research approaches yet strikingly similar results. Wallace (1993) duplicated Peters's methods at eleven terminals within the University of Colorado Library System. ${ }^{5}$ Her efforts spanned twenty hours of search monitoring and resulted in 4,134 logged searches. These were defined by CARL system search type, (e.g., word, subject), then analyzed as cumulative totals and percentages of all searches. In this case, how- 
ever, failed searches (Peters's zero hits) were eliminated entirely from the sample as Wallace focused primarily on patterns of completed searches and did not concern herself with questions of search success or failure, thus limiting the scope of her findings. Among searches analyzed, results were comparable to Peters's. ${ }^{6}$

In keeping with Peters's line of thinking, Wallace remarked,

intriguing vagaries in human behavior during an information search process continue to stymie researchers' efforts to understand that process. . . . Current, widely used and described guidelines, rules and principles of searching simply do not take into account important aspects of what is really going on when an individual is using a computer to search for information. ${ }^{7}$

In 1998, Ciliberti et al. conducted a materials availability study of 441 OPAC searches at Adelphi University over a three-week period during fall semester. ${ }^{8}$ Their work combined Kantor's branching-analysis methodology with transaction-log analysis of OPAC use in order to better understand if users obtain the materials they need through the online catalog. ${ }^{9}$ Sampling was accomplished during random open hours and drew information from undergraduate, graduate, and faculty users. Survey forms included questions of what patrons were searching for. Forms were then picked randomly by staff for re-creation. The study was unclear as to the actual design of these forms and their queries. As a result their effectiveness remains questionable.

A seven-category scheme was developed to code search failures that closely followed Kantor's branching analysis, where the concept of errors extends beyond just OPAC and its design to include such things as library collection development and circulation practices. ${ }^{10}$ The survey itself along with the loss of accuracy that can be expected from patrons attempting to describe their searches on paper, then having these same searches re-created by research staff lead this author to question the data's validity. As Peters has noted, surveys are good for assessing OPAC users' opinions but not necessarily their behavior. ${ }^{11}$ It would seem that in this instance the tool did not fit the task.

This study did, however, use transaction logs after the initial survey analysis and indeed found discrepancies between the self-report (survey) and actual transaction-log data. Search errors were subsequently categorized as previously described. ${ }^{12}$ Though branching analysis is adept at examining on a holistic, entire-library scale (e.g., the question of why patrons are not able to obtain materials), the method's inherent breadth of focus does not lend itself to fine scrutiny of OPAC design issues in and of themselves.

Further refinement of the transaction-log analysis methodology may be seen in Blecic's et al. four-year longitudinal study of OPAC use within the University of Illinois library system. ${ }^{13}$ Once again, failed searches, termed "zero postings" by the authors, were examined as dependent variables and percentages of the total number of searches and were used as a control. Reasons for zero postings (e.g., searches missing search statements, author names entered in incorrect order) fell into seven separate categories. Subsequent transaction-log sets were then culled after three incremental OPAC enhancements. Enhancements included redesigns of general Introductory and Explain screens. Z-test analysis of the level of equality between percentages of zero postings from log set to log set was then made in order to assess whether or not the enhancements had any affect on diminishing said percentages and thus improving searching behavior.

What Blecic et al. found was temporary improvement in patron searches followed by an unexpected lowering of patron performance over time. Confounding attributes to the study include its longitudinal nature in an academic setting where user groups are not constant but variable. Sadly, no attempt at tracking such possible changes in user populations was made. Also of note was the fact that, as time passed, the command-based OPAC was increasingly being surrounded by Web-based journal database search interfaces that did not require the use of sophisticated search statements and arguments. As users became accustomed to this type of searching, their command syntax skills may have suffered as a result. ${ }^{14}$

Merits of the study include its straightforward design, logical data analysis, and plausible conclusions. Longitudinal studies, though prone to the confounding variables described, nevertheless form a persuasive template for further research into how incremental OPAC enhancements affect actual OPAC use over time.

Variations of transaction-log analysis also include the purely experimental. Thomas's 2001 simulation study of eighty-two first-year undergraduates at the University of Pittsburg utilized four separate experimental screen interfaces. ${ }^{15}$ These interfaces included one that mimicked the current catalog with data labels and brief bibliographic displays, a second interface with the same bibliographic display but no data labels, and a third that contained the data labels but modified the brief display to include more subject-oriented fields. A fourth interface viewed the same brief displays as the third group but with the labels removed.

Users were pretested for basic demographic information and randomly assigned to one of the four experimental interface groups. Each group was then given the same two search tasks. For the first task, users were asked to select items that they would examine further for a hypothetical research paper on big-band music and the music of Duke Ellington. The second task involved asking participants to examine twenty bibliographic records and to decide whether they would choose to look into these records further. Participants were then asked to identify the data elements used to inform their 
relevance choices. Resulting user behavior was subsequently tracked through transaction logs.

For Thomas's experimental purposes, though, transaction logs took on a higher level of sophistication than in earlier comparative studies. Here participants' actions were monitored with a greater level of granularity. Quantitative data were tracked for screens visited, time spent viewing them, total number of screens, total number of bibliographic citations examined at each level of specificity, and total time it took to complete the task. Because of the obtrusive nature of the project, a third party was hired to administer the experiment. Chi-square analysis of demographic data found no significance among participant groups in terms of their experience in using computers, online catalogs, or prior knowledge of the problem topic. This important analysis allowed the researchers a higher level of confidence in their subsequent findings.

Results in many instances were, however, inconclusive. Factors impairing the clarity of conclusions included the number of variables analyzed and the artificiality of the test design itself. Thomas comments on one particular example of this:

One of the fields that previous researchers said that library users found important was the call number field. Obviously, without the call number, locating the actual item on the shelf is greatly complicated. In this experiment, however, participants were not asked to retrieve the items they selected; thus, their perceived need for the call number may well have been mitigated. ${ }^{16}$

Here is further evidence that a study of OPAC activity viewed in the context of actual outcomes, namely circulation, is a logical approach to consider.

Most recently, Graham at the University of Lethbridge, Alberta, examined OPAC subject searching and nohit results and considered two possible experimental enhancement types in order to allow users the ability to conduct more accurate searches. ${ }^{17}$ Over a one-week period, 1,521 no-hit subject searches were first sampled and placed into nine categories by error type. Subtotals were then expressed as percentage distributions of the total. A similar examination of 37,987 no-hit findings was also made over the course of four calendar years, forming a longitudinal approach. Percent distribution of error types from the two studies were then compared and were found to be similar with "non-Library of Congress Subject Headings" being the predominant area of concern.

Graham then attempted to improve subject searching by systematically enhancing the catalog in two ways. First, cross-references were created based upon the original nohit search term and linked to existing Library of Congress subject headings (LCSHs) that Graham interpreted as appropriate to the searcher's original intentions. Second, in instances where the original search could not be easily linked to an existing LCSH, a pathfinder record was cre- ated that suggested alternate search strategies. All total, 10,520 new authority records and 2,312 pathfinder records were created over the course of the longitudinal study. ${ }^{18}$

The experiment, unfortunately, only went this far. No attempt was subsequently made to test whether these two methods of adding value to an existing OPAC search interface made a difference in users' experiences. Though creative in its suggested ameliorations to no-hit searches, the study also lacked any statistical testing of comparative data among sample years. Possible problematic design issues, such as the relative complexity of pathfinders and how this might affect their end use were discussed but never tested through the analysis of real outcomes.

In summary, major weaknesses of the transaction-log analysis model as demonstrated through the literature include:

1. Lack of standardization among general study methodologies.

2. Lack of standardization of OPACs themselves: Command structure and screen layout differ among software vendors.

3. Lack of standards on measurable levels of search "success" or "failure."

While the following study of OPAC design enhancements in the public library consortium environment did not directly address the first two points of emphasis, it was this author's expectation that the lack of standardized notions of OPAC search success or failure found throughout the literature may be better addressed through a longitudinal analysis of discrete circulation and ILL statistics. In this way, these quantifiable outcomes, both the direct results of patron initiation, would better assume clearer measures of patron success or failure in OPAC end use.

\section{Purpose and methodology}

In recent years, both academic and public libraries have invested substantial capital in improving OPAC design and automated systems. To what extent have these improvements affected the use of library materials by public library patrons?

In order to better examine the question, this study tracked, over a seven-year period dating back from July 1998 through June 2005, the circulation and systemwide holds statistical trends of sixteen member libraries of C/ W MARS, a Massachusetts automated library network of 140 libraries. During this time a number of discrete, incremental OPAC modifications granted patrons the ability to accomplish tasks remotely through the OPAC that previously had required library staff mediation. Among these 
changes, the initiation of intra-consortium (C/W MARS) patron-placed holds, and the subsequent introduction of a link from the existing OPAC to the Massachusetts Virtual Catalog (nine Massachusetts consortiums, four University of Massachusetts System Libraries) were examined.

This author hypothesized that such OPAC enhancements that allow for broader choices of patron-placed holds would result in increases in both total circulation and total network transfers (ILL) of library materials one year after initial enhancement adoption. As both total circulation and total ILL grew, it was hypothesized that ILL as a percent of total circulation would likewise increase due to the fact that each OPAC enhancement was targeted directly toward facets of ILL procurement.

OPAC enhancements followed the schedule below:

1. General C/W MARS network systemwide holds (requests mediated through library staff only), November 2000

2. Patron-placed holds (request button placed on C/ W MARS OPAC screens), December 2002

3. C/W MARS participation in the Massachusetts Virtual Catalog (additional button for pass through OPAC searches and requests from $\mathrm{C} / \mathrm{W}$ MARS catalog into the Massachusetts Virtual Catalog), August 2004

These dates served as independent variables in a study of separate dependent variables (total circulation and total ILLs received) for all eight libraries one year after initial adoption of a new enhancement. For the sake of continuity the terms Holds and ILLs were used interchangeably throughout this examination. T-test comparisons to figures from the year prior to enhancement were then made for statistical significance. In addition, ILLs received as a percentage of total circulation (dependent variable) for all fifteen libraries one year after initial adoption of a new enhancement were also calculated and compared to the year prior to enhancement through Z-test analysis.

Libraries chosen were a random sample from both central and western geographic regions of the network. Sampled institutions did not go through any substantial renovations, drastic open hours changes, or closures during the study period in order to better avoid potential confounding variables that may have skewed the resulting data. Raw circulation and ILL figures were taken directly from the Massachusetts Board of Library Commissioners' (MBLC) data files for fiscal years 1999 through 2004. ${ }^{19}$ In the MBLC's data files, the following fields, sorted by library, correlated to this study's statistical reporting:

"DIRCIRC" = "Circulation"

"LOAN FROM" = "ILL"
As fiscal year (FY) 2005 figures for circulation and ILL had not yet been compiled by MBLC at the time of this writing, these statistics were in turn taken directly from reports run off of $\mathrm{C} / \mathrm{W}$ MARS's network servers. It should be noted that similar C/W MARS reports are distributed and used by the consortium's libraries themselves each fiscal year for reporting circulation and ILL statistics to MBLC.

Raw data by library were entered into Microsoft Excel spreadsheets. Totals for circulation and ILLs received for all libraries by FY of OPAC enhancement were totaled and then compared to FY data prior to enhancement as a percent change value. Excel's Data Analysis Tools were then employed to run t-tests (paired two sample for means) in tables 1 through 5 to analyze the level of change for significance from one sample to the next in both total circulation and total ILLs. (All tables and charts can be found in appendix following article.) Tests for significance employed two-tailed t-tests with an alpha level set to .05 .

Raw data for these same libraries across identical study years were also entered into subsequent spreadsheets (tables 6 through 10) for additional z-tests (two samples for means) to analyze the level of change for significance from one FY sample to the next in ILLs received as a percentage of total circulation. Here tests for significance employed two-tailed z-tests with an alpha level set to .05 .

\section{Results and discussion}

The results of a sixteen-library, seven-year longitudinal study of total circulation and total ILLs-received statistics are outlined in tables 1 through 5, charts 1 through 10 . In addition, an analysis of ILLs received as a percentage of total circulation during this same time period among sampled libraries is represented in tables 6 through 10 . Over the course of the study a total of $22,277,245$ circulation and 624,286 ILL transactions were examined from July 1998 through June 2005.

Yearly comparisons in total circulation and total ILLs received from FY '99 to FY '00 were made to analyze the level of changes in circulation and ILL statistics between years before any OPAC ILL enhancements were undertaken. As such these numbers gave insight into what changes, if any, normally occur in circulation and ILL figures prior to a schedule of substantial OPAC ILL enhancements. Although the year-to-year comparisons over the course of subsequent enhancement rollouts were made to test for the statistical significance of the year prior and following a particular functionality addition, the ' 99 to '00 
comparison was made to form a control of what circulation and ILL trends may look like between years of no drastic workflow or design changes.

Results showed that this yearly comparison prior to the beginning of OPAC enhancements (table 1, charts 1 and 2) showed no significant change from one year to the next in total circulation $(\mathrm{t}=1.81, \mathrm{p}>0.05)$ or total ILLs received $(t=-0.76, p>0.05)$. Circulation from ' 99 to '00 declined slightly by 3.42 percent while total ILLs received increased 3.35 percent. The MBLC's available retrospective data set currently only goes back to FY' 99 , so a deeper understanding beyond this two-year comparison of normal year-to-year trends was impossible to achieve. Yet data from this sample suggest that both circulation and ILLs may trend statistically flat from one year of little if any alteration of ILL design to the next.

Additionally, comparisons of the percent of total ILLs received to total circulation were made between '99 and '00 (as will be seen in table 6) and were found to be insignificantly different $(z=-0.23, p>0.05)$. ILLs received made up 0.61 percent of total circulation in FY' 99 and 0.65 percent of total circulation in $\mathrm{FY}$ '00.

During FY '01 (November 2001), C/W MARS rolled out automated systemwide holds functionality whereby library staff were first able to place patron requests for materials at other C/W MARS member libraries through the consortium's automated circulation system. Up until this point, holds (ILLs) were placed primarily by staff through e-mail or faxed requests from one ILL department to another. Patrons would request material either verbally with staff or through the submission of a paper or electronic form. Staff would then look up the item in the electronic catalog and make the request.

With the advent of systemwide holds, staff still accepted requests in a similar fashion, but instead of using the fax or e-mail, they began to place requests directly into the network's Innovative Millennium circulation clients. From there, the automated system not only randomly chose the lending library within the system but also automatically queued paging slips at the lending library for material that would subsequently be sent in transit to the borrowing location.

By this time in the network's development, OPAC had also graduated from a character-based telnet system to a smoother Web design. But the catalog, in terms of directly assisting in the placing of ILL requests, functioned as it always had-it was still individually a searching mechanism.

The introduction of systemwide holds led to the second largest jump in ILL figures out of all comparative samples (table 2, chart 4). Interestingly enough, the considerably significant 127.23 -percent gain in ILL activity from $F Y^{\prime} 00$ to $F Y^{\prime} 01(\mathrm{t}=-4.07, \mathrm{p}<0.05)$ did not translate into a significant increase in total circulation. In fact, circulation declined during this period, not significantly $(\mathrm{t}$
$=1.87, \mathrm{p}>0.05$ ), but by 2.40 percent nonetheless (table 2 , chart 5). A comparison of the percent of ILLs to total circulation from FY '00 to FY '01 (table 7) indicated a significant increase of 0.65 percent to 1.52 percent $(z=-4.20$, $\mathrm{p}<0.05)$. More on the possible effects to circulation that rising levels of ILLs may elicit will be touched upon.

Though no statistical evaluations were made between FY '01 and FY '02 (as no novel ILL changes were made over this period), it should be noted that during FY '02 the network first allowed patrons the ability, through OPAC, to log into their own accounts remotely. Patrons were given the ability to set up a personal identification number and view such things as a list of their checkedout items. Patrons were also allowed to place checks next to such items and to renew these items remotely.

FY '03 saw the original direct ILL enhancement to OPAC. During this year patrons were first given the opportunity to directly place ILL requests of their own (patron-placed holds) for material found in the catalog through the addition of an OPAC screen request button. Up until this time, all material requests had been mediated by library staff.

Comparative total circulation results from the year before enhancement to FY '03 (table 3, chart 5) showed only a slightly significant 4.18 percent increase $(\mathrm{t}=-2.94$, $\mathrm{p}<0.05$ ). ILLs-received figures (table 3, chart 6), however, jumped by a considerable 25.58 percent margin $(t=-4.66$, $p<0.05)$, strongly suggesting that the OPAC requestbutton addition and its facilitation of patron-placed holds had a positive effect upon total ILL activity as was hypothesized. Finally, total ILLs received as a percentage of total circulation increased slightly from FY '02 (2.52 percent) to FY '03 (3.04 percent) (table 8) but did not represent a significant shift $(\mathrm{z}=-1.51, \mathrm{p}>0.05)$.

The last augmentation to the network's OPAC design that this study examined was an additional link for ILLs through the Massachusetts Virtual Catalog. The Massachusetts Virtual Catalog at the time of this study was an online union catalog of nine Massachusetts network consortia and four University of Massachusetts System Libraries.

Unlike the previous request-button enhancement that allowed for seamless patron-placed holds within the C/ W MARS catalog, the Massachusetts Virtual Catalog link was not a button but a descriptive hyperlink (Can't find the title you want here? Try the Massachusetts Virtual Catalog next!) from the network's OPAC to the Virtual Catalog's own dedicated OPAC interface. Once there, patrons were required to login to the Virtual Catalog and re-create their search queries from scratch as previous searches were not automatically passed through to the second catalog. In essence, the Virtual Catalog acted as an additional step for patrons to take beyond C/W MARS's list of holdings to broaden their search for materials that the network's member libraries did not own. 
Comparative figures for total circulation between FY '04 and FY '05 (table 4, chart 7) when the Virtual Catalog link was added to the $\mathrm{C} / \mathrm{W}$ MARS OPAC screen found circulation down an insignificant 2.04 percent $(t=0.97$, $\mathrm{p}$ $>0.05)$, which ran counter to hypothesized expectations. Total ILLs received between FY'04 and FY '05 (table 4, chart 8), however, rose 30.85 percent, which proved to be a highly significant increase $(t=-7.03, p<0.05)$. Additionally ILLs as a percent of total circulation rose from 4.70 percent in FY '04 to 6.27 percent in FY'05 (table 9), which was statistically significant $(z=-3.28, p<0.05)$ and pointed to not only gains in ILL itself after the introduction of the Virtual Catalog link but also to the ever increasing proportion of total circulation that ILL activity accounted for.

The final statistical comparison accomplished in this study was a look at what possible cumulative effect, if any, both OPAC enhancements may have had from the year before the first enhancement's rollout (patron-placed holds Request button) to one year after the latest addition (Virtual Catalog hyperlink from OPAC). In turn, comparative numbers for circulation and ILLs between FY '02 and FY '05 were examined.

Total circulation over this time (table 5, chart 9) increased insignificantly by 3.46 percent $(t=-1.47$, $\mathrm{p}$ $>0.05)$. Total ILLs received (table 5, chart 10), however, increased by 157.47 percent, the highest significant increase of any two comparative samples $(t=-7.20, p<$ $0.05)$. ILLs as a percent of total circulation also increased significantly from 2.52 percent in FY '02 to 6.27 percent in FY'05 ( $\mathrm{z}=-7.71, \mathrm{p}<0.05)$ (table 10).

If one steps back and examines the various comparisons discussed up to this point, certain trends become evident. Over the course of the seven-year study, total circulation remained relatively flat, oscillating slightly back and forth, year to year with only one significant increase that occurred after the introduction of patronplaced holds in FY '03. These results, excluding FY '03, ran against hypothesized expectations that predicted that as ILL enhancements were rolled out, correspondingly significant increases in circulation would result.

Total ILLs received (the FY '99 to FY '00 control comparison) before the advent of first, network systemwide holds, then a succession of OPAC design enhancements that allowed for a broader range of patron-initiated ILLs suggested that these totals run statistically flat from one year to the next. With the advent of systemwide holds, the ILL picture, however, began to change dramatically with a significant increase in total ILLs. This was followed by significant increases in ILL activity in each study year that came after an OPAC ILL enhancement. These results pointed toward the substantial effect that these enhancements made in total ILL activity and supported hypothesized expectations.

When such OPAC rollouts were examined as a cumulative influence through the prism of ILL levels of this past fiscal year (FY'05) compared to the year before their initial advent (FY'02), the positive effect that such enrichments had on not only total ILL but also on total circulation becomes clearest. For it is through this comparison that it was found that not only did total ILLs increase significantly but that ILLs as a percentage of total circulation also increased significantly from the time before the first OPAC enhancement to the present. Total circulation was surprisingly impervious to change and ran statistically flat during this time.

It is clear from this longitudinal study that incrementally granting patrons access to online tools for them to initiate such traditional library business as ILLs spurs significantly large increases in such activity. In other words, these online tools are not ignored but are intellectually and literally grasped. What may be surprising, however, is the degree to which ILL has increased as a result of them, to a point where ILL has not only taken up a significantly greater proportion of total circulation than ever before but also appears to be changing the very nature of circulation itself.

Future studies may include a deeper examination of the circulation and ILL statistical picture farther back in time than this investigation covers to better clarify trends leading up to such major enhancement rollouts. Also, similar longitudinal studies from different consortia environments may shed further light on evidence discussed throughout this writing. Consortia are uniquely poised to offer large statistical sample sizes and standardized workflows within their network-wide ILL and circulation software packages and automated statistical programs. This, in turn, results in high-quality, consistent data samples from heterogeneous library sources that are relatively uncorrupted by scattershot recording methods and differing circulation and ILL methodologies.

Finally, a future look at the effects that similar OPAC ILL enhancements may have on borrowing trends beyond general raw transactional figures is warranted. Chris Anderson, for example, has recently commented on Long Tail statistical analysis and its relation to library catalogs. Here outwardly shifting demand curves for library materials are hypothesized as collections become more visible and interconnected through the Web. ${ }^{20}$ In a similar vein, a more granular examination of such concepts as possible circulation and ILL-activity trends in terms of discrete material types borrowed, patron types who borrow, or a cross-tabulation of these data points would appear to be a fertile next step toward a greater knowledge of ILLs and circulation as a whole.

\section{References}

1. T. Peters, "When Smart People Fail: An Analysis of the Transaction Log of an Online Public Access Catalog," The Journal of Academic Librarianship 15, no. 5 (1989): 267-73. 
2. Ibid., 272.

3. Ibid.

4. Ibid., 272.

5. P. Wallace, "How Do Patrons Search the Online Catalog When No One's Looking? Transaction-Log Analysis and Implications for Bibliographic Instruction and System Design," RQ 33, no. 2 (1993): 239-43.

6. Peters, "When Smart People Fail."

7. Wallace, "How Do Patrons Search the Online Catalog When No One's Looking?" 239.

8. A. Ciliberti et al., "Empty Handed? A Material Availability Study and Transaction-Log Analysis Verification," The Journal of Academic Librarianship 24, no. 4 (1998): 282-89.

9. P. Kantor, "Availability Analysis," Journal of the American Society for Information Science 27, nos. 5-6 (1976): 311-19.

10. Ciliberti et al., "Empty Handed? A Material Availability Study and Transaction-Log Analysis Verification."

11. Peters, "When Smart People Fail."

12. Ciliberti et al., "Empty Handed? A Material Availability Study and Transaction-Log Analysis Verification."
13. D. Blecic, et al., "A Longitudinal Study of the Effects of OPAC Screen Changes on Searching Behavior and Searcher Success," College \& Research Libraries 60, no. 6 (1999): 515-30.

14. Ibid.

15. D. Thomas, "The Effect of Interface Design on Item Selection in an Online Catalog," Library Resources $\mathcal{E}$ Technical Services 45 , no. 1 (2001): 20-46.

16. Ibid., 41 .

17. R. Graham, "Subject No-Hits Searches in an Academic Library Online Catalog: An Exploration of Two Potential Ameliorations," College E Research Libraries 65, no. 1 (2004): 36-54.

18. Ibid.

19. Massachusetts Board of Library Commissioners 2005, "Public Library Data, Data Files," http://www.mlin.lib.ma.us/ advisory/statistics/public/index.php (accessed Oct. 13, 2005).

20. C. Anderson, "The Long Tail," Wired Magazine 12, no. 10 (2004): 170-77; "Q\&A with Chris Anderson," OCLC Newsletter, 2005, no. 268, http://www.oclc.org/news/publications/news letters/oclc/2005/268/interview.htm (accessed July 20, 2006).

\section{Appendix A: Tables and Charts}

Table 1. Yearly comparison prior to the beginning of ILL OPAC enhancements

\begin{tabular}{|c|c|c|c|c|c|c|}
\hline LIBRARIES & $\begin{array}{c}\text { Total Circulation } \\
\text { FY' } 99\end{array}$ & $\begin{array}{c}\text { Total Circulation } \\
\text { FY vo }\end{array}$ & \%change & \begin{tabular}{|c|} 
Total ILL Recelved \\
FY' 99 \\
\end{tabular} & $\begin{array}{c}\text { Total ILL Received } \\
\text { FYoo } \\
\end{array}$ & \% Change \\
\hline Amherst & 514799 & 501725 & $-2.54 \%$ & 951 & 1219 & $28.18 \%$ \\
\hline Auburn & 199170 & 198728 & $-0.22 \%$ & 467 & 453 & $-3.00 \%$ \\
\hline Belchertown & 148051 & 125424 & $-15.28 \%$ & 2341 & 1869 & $-20.16 \%$ \\
\hline Bellingham & 93412 & 98004 & $4.92 \%$ & 470 & 417 & $-11.28 \%$ \\
\hline Dudley & 60064 & 57974 & $-3.48 \%$ & 484 & 493 & $1.86 \%$ \\
\hline Harvard & 66262 & 64255 & $-3.03 \%$ & 1397 & 1358 & $-2.79 \%$ \\
\hline Holden & 214275 & 224480 & $4.76 \%$ & 1411 & 1806 & $27.99 \%$ \\
\hline Hudson & 128692 & 136458 & $6.03 \%$ & 1082 & 1191 & $10.07 \%$ \\
\hline Marlborough & 207336 & 210268 & $1.41 \%$ & 1350 & 1634 & $21.04 \%$ \\
\hline Milford & 203508 & 186939 & $-7.16 \%$ & 1314 & 1354 & $3.04 \%$ \\
\hline Pittsfield & 284564 & 280269 & $-1.51 \%$ & 2161 & 2069 & $-4.26 \%$ \\
\hline Shrewsbury & 252549 & 260948 & $3.33 \%$ & 1708 & 1601 & $-6.26 \%$ \\
\hline South Hadley & 205812 & 155970 & $-24.22 \%$ & 927 & 853 & $-7.98 \%$ \\
\hline West Springfield & 207875 & 198547 & $-4.49 \%$ & 1045 & 1430 & $36.84 \%$ \\
\hline Westfield & 302734 & 284506 & $-6.02 \%$ & 1454 & 1485 & $2.13 \%$ \\
\hline Williamstown & 102598 & 96165 & $-6.27 \%$ & 919 & 902 & $-1.85 \%$ \\
\hline Totals & 3191701 & 3082660 & $-3.42 \%$ & 19481 & 20134 & $3.35 \%$ \\
\hline \multicolumn{7}{|c|}{ T-Test: Paired Two Sample For Means } \\
\hline & $\begin{array}{c}\text { Total Croculation } \\
\text { FY' } 99\end{array}$ & $\begin{array}{c}\text { Total Circulation } \\
\text { FY'00 }\end{array}$ & & $\begin{array}{c}\text { TotaliLL } \\
\text { Recalved FY'gg }\end{array}$ & $\begin{array}{c}\text { Totallil } \\
\text { Received Froo }\end{array}$ & \\
\hline Mean & 199481.3125 & 192666.25 & & 1217.5625 & 1258.375 & \\
\hline Variance & 12401789872 & 11975202201 & & 299977.1958 & 261866.65 & \\
\hline Observations & & 16 & & & 16 & \\
\hline Pearson Correlation & 0.990884409 & & & 0.919318329 & & \\
\hline $\begin{array}{l}\text { Hypothesized Mean } \\
\text { Difference }\end{array}$ & 0 & & & 0 & & \\
\hline di & 15 & & & 15 & & \\
\hline t Stat & 1.813687961 & & & -0.757004672 & & \\
\hline$P(T<=t)$ one-tail & 0.044889697 & & & 0.230386672 & & \\
\hline$t$ Critical one-tail & 1.753050325 & & & 1.753050325 & & \\
\hline$P(T<=t)$ two-tail & 0.089779394 & & & 0.460773344 & & \\
\hline t Critical two-tail & 2.131449536 & & & 2.131449536 & & \\
\hline
\end{tabular}

Table 2. General systemwide holds implementation (adopted 11/00)

\begin{tabular}{|c|c|c|c|c|c|c|}
\hline LUBRARIES & $\begin{array}{c}\text { Total Circulation } \\
\text { FY'no }\end{array}$ & $\begin{array}{c}\text { Total Circulation } \\
\text { FY vo }\end{array}$ & \% Change & \begin{tabular}{|c|} 
Total ILL Recelved \\
FY 'co
\end{tabular} & $\begin{array}{c}\text { Totol ILL Recelved } \\
\text { FYro1 }\end{array}$ & \% Change \\
\hline Amherst & 501725 & 504137 & $0.48 \%$ & 1219 & 8041 & $559.64 \%$ \\
\hline Auburn & 198728 & 192087 & $-3.34 \%$ & 453 & 1274 & $181.24 \%$ \\
\hline Belchertown & 125424 & 128084 & $2.12 \%$ & 1869 & 3413 & $82.61 \%$ \\
\hline Bellingham & 98004 & 67812 & $-30.81 \%$ & 417 & 610 & $46.28 \%$ \\
\hline Dudley & 57974 & 54962 & $.520 \%$ & 493 & 1231 & $149.70 \%$ \\
\hline Harvard & 64255 & 64998 & $1.16 \%$ & 1358 & 1578 & $16.20 \%$ \\
\hline Holden & 224480 & 220763 & $-1.66 \%$ & 1806 & 2406 & $33.22 \%$ \\
\hline Hudson & 136458 & 136185 & $-0.20 \%$ & 1191 & 2441 & $104.95 \%$ \\
\hline Marlborough & 210268 & 202629 & $-3.63 \%$ & 1634 & 2803 & $71.54 \%$ \\
\hline Milford & 188939 & 172672 & $-8.61 \%$ & 1354 & 2318 & $71.20 \%$ \\
\hline Pittsfield & 280269 & 286814 & $2.34 \%$ & 2069 & 4712 & $127.74 \%$ \\
\hline Shrewsbury & 260948 & 258798 & $-0.82 \%$ & 1601 & 3228 & $101.62 \%$ \\
\hline South Hadley & 155970 & 149607 & $.4 .08 \%$ & 853 & 1577 & $84.88 \%$ \\
\hline West Springfield & 198547 & 196203 & $-0.17 \%$ & 1430 & 3114 & $117.76 \%$ \\
\hline Westfield & 284506 & 266151 & $-6.45 \%$ & 1485 & 3842 & $158.72 \%$ \\
\hline Williamstown & 96165 & 104767 & $8.95 \%$ & 902 & 3163 & $250.67 \%$ \\
\hline Totals & 3082660 & 3008669 & $-2.40 \%$ & 20134 & 45751 & $127.23 \%$ \\
\hline \multicolumn{7}{|c|}{ I-Test: Paired Two Sample For Means } \\
\hline & $\begin{array}{l}\text { Total Cliculation } \\
\text { FY vo }\end{array}$ & $\begin{array}{l}\text { Total Circulation } \\
\text { FY } 01\end{array}$ & & $\begin{array}{c}\text { TotalliLL } \\
\text { Recoived } F Y \text { yo }\end{array}$ & $\begin{array}{l}\text { Total/LL } \\
\text { Recoived Fro1 }\end{array}$ & \\
\hline Mean & 192666.25 & 188041.8125 & & 1258.375 & 2859.4375 & \\
\hline & 1197520 & 12 & & 26 & 3068958.796 & \\
\hline Observations & 16 & 16 & & 16 & 16 & \\
\hline Pearson Correlation & 0.996043325 & & & 0.478555251 & & \\
\hline $\begin{array}{l}\text { Hypothesized Mean } \\
\text { Oifterence }\end{array}$ & 0 & & & 0 & & \\
\hline $\mathrm{dt}$ & 15 & & & 15 & & \\
\hline t Stat & 1.867383605 & & & -4.07261 & & \\
\hline t) one-tail & 0. & & & 0.0005 & & \\
\hline tCritical one-tail & 1.753051038 & & & 1.753051038 & & \\
\hline$P(T<-t)$ two-tail & $\begin{array}{l}0.081512831 \\
2.131450856\end{array}$ & & & $\begin{array}{l}0.001000305 \\
2.131450856\end{array}$ & & \\
\hline
\end{tabular}


Table 3. OPAC design enhancement: patron-placed holds (adopted 12/02)

\begin{tabular}{|c|c|c|c|c|c|c|}
\hline LIBRARIES & $\begin{array}{c}\text { Tolal Circulation } \\
\text { FY'02 } \\
\end{array}$ & \begin{tabular}{|c|} 
Total Circulation \\
FY'03 \\
\end{tabular} & \% Change & \begin{tabular}{|c|} 
Total ILL Received \\
FY O2 \\
\end{tabular} & $\begin{array}{c}\text { Total ILL Received } \\
\text { Fro3 } \\
\end{array}$ & \% Change \\
\hline Amherst & 526855 & 547139 & $3.85 \%$ & 13614 & 18277 & $34.25 \%$ \\
\hline Auburn & 189169 & 182029 & $-3.77 \%$ & 2799 & 4504 & $60.91 \%$ \\
\hline Belchertown & 130562 & 134183 & $2.77 \%$ & 5252 & 6511 & $23.97 \%$ \\
\hline Bellingham & 67667 & 76067 & $12.41 \%$ & 1259 & 2546 & $102.22 \%$ \\
\hline Dudley & 55500 & 54478 & $-1.84 \%$ & 1281 & 1585 & $23.73 \%$ \\
\hline Harvard & 68125 & 72339 & $6.19 \%$ & 3418 & 4135 & $20.98 \%$ \\
\hline Holden & 248615 & 278296 & $11.94 \%$ & 4802 & 6215 & $29.43 \%$ \\
\hline Hudson & 142075 & 156275 & $9.99 \%$ & 4828 & 5755 & $19.20 \%$ \\
\hline Marlborough & 191491 & 201183 & $5.06 \%$ & 4522 & 5855 & $29.48 \%$ \\
\hline Milford & 180012 & 183803 & $2.11 \%$ & 5850 & 7610 & $30.09 \%$ \\
\hline Pittsfield & 301878 & 297840 & $-1.34 \%$ & 6944 & 7594 & $9.36 \%$ \\
\hline Shrewsbury & 266159 & 297744 & $11.87 \%$ & 5358 & 7198 & $34.34 \%$ \\
\hline South Hadley & 156855 & 157005 & $0.10 \%$ & 2588 & 3187 & $23.15 \%$ \\
\hline West Springfield & 214549 & 220851 & $2.94 \%$ & 5680 & 7091 & $24.84 \%$ \\
\hline Westfield & 283032 & 283039 & $0.00 \%$ & 5726 & 5240 & $-8.49 \%$ \\
\hline Williamstown & 121875 & 133537 & $9.57 \%$ & 5352 & 6251 & $16.80 \%$ \\
\hline Totals & 3144419 & 3275808 & $4.18 \%$ & 79273 & 99554 & $25.58 \%$ \\
\hline \multicolumn{7}{|c|}{ t-Test: Paired Two Sample For Means } \\
\hline & $\begin{array}{c}\text { Total Criculation } \\
\text { FY'02 }\end{array}$ & $\begin{array}{l}\text { Total Circulation } \\
\text { FY } 03\end{array}$ & & $\begin{array}{c}\text { TotalllLL } \\
\text { Received FY } 02\end{array}$ & $\begin{array}{c}\text { TotalllL } \\
\text { Received Fros }\end{array}$ & \\
\hline \begin{tabular}{|l} 
Mean \\
\end{tabular} & 196526.1875 & 204738 & & 4954.5625 & 6222.125 & \\
\hline Variance & 13558741886 & 14577539335 & & 8084188.663 & 13584951.05 & \\
\hline Observations & & 16 & & 16 & 16 & \\
\hline Pearson Correlation & 0.996230737 & & & 0.97749141 & & \\
\hline $\begin{array}{l}\text { Hypothesized Mean } \\
\text { Difterence }\end{array}$ & 0 & & & 0 & & \\
\hline dt & 15 & & & 15 & & \\
\hline t Stat & -2.944614982 & & & -4.664419087 & & \\
\hline$P(T<=1)$ one-tail & 0.005021359 & & & 0.00015272 & & \\
\hline t Critical one-tail & 1.753051038 & & & 1.753051038 & & \\
\hline$P(T<=1)$ two-tail & 0.010042719 & & & 0.00030544 & & \\
\hline t Critical two-tail & 2.131450856 & & & 2.131450856 & & \\
\hline
\end{tabular}

Table 5. OPAC design enhancements: "Cumulative Effect" (FY '02 to $\mathrm{FY}$ '05)

\begin{tabular}{|c|c|c|c|c|c|c|}
\hline LUBRARIES & $\begin{array}{c}\text { Total Circulation } \\
\text { Fr } 02 \\
\end{array}$ & $\begin{array}{c}\text { Total Circulation } \\
\text { FY OS } \\
\end{array}$ & \%change & \begin{tabular}{|c|} 
Total ILL Recelved \\
FY 02 \\
\end{tabular} & $\begin{array}{c}\text { Total ILL Recelved } \\
\text { FYos } \\
\end{array}$ & s Change \\
\hline Amherst & 526855 & 508376 & $-3.51 \%$ & 13614 & 34294 & $151.90 \%$ \\
\hline Auburn & 189169 & 195533 & $3.36 \%$ & 2799 & 10561 & $277.31 \%$ \\
\hline Belchertown & 130562 & 144356 & $10.57 \%$ & 5252 & 13131 & $150.02 \%$ \\
\hline Bellingham & 67667 & 80408 & $18.83 \%$ & 1259 & 5441 & $332.17 \%$ \\
\hline Dudley & 55500 & 37700 & $-32.07 \%$ & 1281 & 4104 & $220.37 \%$ \\
\hline Harvard & 68125 & 74401 & $9.21 \%$ & 3418 & 7494 & $119.25 \%$ \\
\hline Holden & 248615 & 241037 & $-3.05 \%$ & 4802 & 12799 & $166.53 \%$ \\
\hline Hudson & 142075 & 175127 & $23.26 \%$ & 4828 & 11903 & $146.54 \%$ \\
\hline Marlborough & 191491 & 197673 & $3.23 \%$ & 4522 & 12445 & $175.21 \%$ \\
\hline Milford & 180012 & 181661 & $0.92 \%$ & 5850 & 12077 & $106.44 \%$ \\
\hline Pittsfield & 301878 & 287578 & $-4.74 \%$ & 6944 & 17123 & $146.59 \%$ \\
\hline Shrewsbury & 266159 & 314398 & $18.12 \%$ & 5358 & 18774 & $250.39 \%$ \\
\hline South Hadley & 156855 & 154360 & $-1.59 \%$ & 2588 & 7516 & $190.42 \%$ \\
\hline West Springfield & 214549 & 237650 & $10.77 \%$ & 5680 & 14964 & $163.45 \%$ \\
\hline Westfield & 283032 & 278943 & $.1 .44 \%$ & 5726 & 11104 & $93.92 \%$ \\
\hline Williamstown & 121875 & 143904 & $18.08 \%$ & 5352 & 10374 & $93.83 \%$ \\
\hline Totals & 3144419 & 3253105 & $3.46 \%$ & 79273 & 204104 & $157.47 \%$ \\
\hline \multicolumn{7}{|c|}{ 1-Test: Paired Two Sample For Means } \\
\hline & $\begin{array}{c}\text { Total Circulation } \\
\text { FY } 02\end{array}$ & $\begin{array}{l}\text { Total Circulation } \\
\text { FY 05 }\end{array}$ & & $\begin{array}{c}\text { Total ILL } \\
\text { Received FY } 02\end{array}$ & $\begin{array}{c}\text { TotalllL } \\
\text { Received FYos }\end{array}$ & \\
\hline Mean & 196526.1875 & 203319.0625 & & 4954.5625 & 12756.5 & \\
\hline Variance & 13558741886 & 12715659137 & & 8084188.663 & 48147279.2 & \\
\hline Observations & 16 & 16 & & 16 & 16 & \\
\hline Pearson Correlation & 0.987525828 & & & 0.948782049 & & \\
\hline $\begin{array}{l}\text { Hypothesized Mean } \\
\text { Difference }\end{array}$ & 0 & & & 0 & & \\
\hline df & 15 & & & 15 & & \\
\hline t Stat & -1. & & & -7.198 & & \\
\hline$P(T<-t)$ one-tal & 0.0809 & & & 1.54 & & \\
\hline t Critical one-tail & 1.753050325 & & & 1.753050325 & & \\
\hline$P(T<=1)$ two-tail & 0.161909954 & & & $3.08061 \mathrm{E}-06$ & & \\
\hline i Critical two-tail & 2.131449536 & & & 2.131449536 & & \\
\hline
\end{tabular}

Table 4. OPAC design enhancement: patron-placed Massachusetts virtual catalog holds (adopted 8/04)

\begin{tabular}{|c|c|c|c|c|c|c|}
\hline LIBRARIES & $\begin{array}{c}\text { Total Circulation } \\
\text { FY'ous } \\
\end{array}$ & $\begin{array}{c}\text { Total Circulation } \\
\text { FY } 05\end{array}$ & \% Change & \begin{tabular}{|c|} 
Total ILL. Recelved \\
Fr' O4 \\
\end{tabular} & \begin{tabular}{|c|} 
Total ILL Recelved \\
Fros \\
\end{tabular} & \% Change \\
\hline Amherst & 507103 & 508376 & $0.25 \%$ & 27338 & 34294 & $25.44 \%$ \\
\hline Auburn & 190995 & 185533 & $2.38 \%$ & 8719 & 10561 & $21.13 \%$ \\
\hline Belchertown & 136064 & 144356 & $6.09 \%$ & 9037 & 13131 & $45.30 \%$ \\
\hline Bellingham & 89439 & 80408 & $-10.10 \%$ & 4487 & 5441 & $21.26 \%$ \\
\hline Dudley & 48793 & 37700 & $-22.73 \%$ & 2809 & 4104 & $46.10 \%$ \\
\hline Harvard & 74198 & 74401 & $0.27 \%$ & 5827 & 7494 & $28.61 \%$ \\
\hline Holden & 294933 & 241037 & $-18.27 \%$ & 11969 & 12799 & $6.93 \%$ \\
\hline Hudson & 156393 & 175127 & $11.98 \%$ & 8508 & 11903 & $39.90 \%$ \\
\hline Marlborough & 209168 & 197673 & $-5.50 \%$ & 9794 & 12445 & $27.07 \%$ \\
\hline Miltord & 204261 & 181661 & $-11.06 \%$ & 9933 & 12077 & $21.58 \%$ \\
\hline Pittsfield & 280770 & 287578 & $2.42 \%$ & 12191 & 17123 & $40.46 \%$ \\
\hline Shrewsbury & 333712 & 314398 & $-5.79 \%$ & 13415 & 18774 & $39.95 \%$ \\
\hline South Hadley & 156502 & 154360 & $-1.37 \%$ & 4908 & 7516 & $53.14 \%$ \\
\hline West Springfield & 233697 & 237650 & $1.69 \%$ & 10970 & 14964 & $36.41 \%$ \\
\hline Westfield & 265100 & 278943 & $5.22 \%$ & 7889 & 11104 & $40.75 \%$ \\
\hline Williamstown & 139755 & 143904 & $2.97 \%$ & 8195 & 10374 & $26.59 \%$ \\
\hline Totals & 3320883 & 3253105 & $-2.04 \%$ & 155989 & 204104 & $30.85 \%$ \\
\hline \multicolumn{7}{|c|}{ T-Test: Paired Two Sample For Means } \\
\hline & $\begin{array}{c}\text { Total Circulation } \\
\text { FY } 04\end{array}$ & $\begin{array}{c}\text { Total Circulation } \\
\text { FY 05 }\end{array}$ & & $\begin{array}{c}\text { Total IIL } \\
\text { Received FY o4 }\end{array}$ & $\begin{array}{c}\text { Total IIL } \\
\text { Received Fros }\end{array}$ & \\
\hline Mean & 207555.1875 & 203319.0625 & & 97493125 & 12756.5 & \\
\hline Variance & 12986338316 & 12715659137 & & 30592200.76 & 48147279.2 & \\
\hline Observations & 16 & 16 & & 16 & 16 & \\
\hline Pearson Correlation & 0.982238387 & & & 0.987660493 & & \\
\hline $\begin{array}{l}\text { Hypothesized Moan } \\
\text { Difference }\end{array}$ & 0 & & & 0 & & \\
\hline df & $\begin{array}{r}15 \\
097204719\end{array}$ & & & $\begin{array}{r}15 \\
7528400501\end{array}$ & & \\
\hline t Stat & 0.972304719 & & & -7.028400501 & & \\
\hline$P(T<=t)$ one-tail & 0.173159102 & & & $2.04108 E-06$ & & \\
\hline t Critical one-tail & 1.753050325 & & & 1.753050325 & & \\
\hline$P(T<-1)$ two-tail & 0.346318204 & & & $4.08215 E-06$ & & \\
\hline tCritical two tail & 2.131449538 & & & 2.131449536 & & \\
\hline
\end{tabular}

Table 6. Yearly comparison prior to the beginning of ILL OPAC enhancements of ILL received as a percentage of total circulation

\begin{tabular}{|c|c|c|c|c|c|c|}
\hline LIBRAAIES & $\begin{array}{c}\begin{array}{c}\text { Total Circulation } \\
\text { FY } 99\end{array} \\
\end{array}$ & \begin{tabular}{|c}
$\begin{array}{c}\text { Total ILL Recelved } \\
\text { FY } 99\end{array}$ \\
\end{tabular} & \begin{tabular}{|c|} 
ILL as \%or \\
Total Circ \\
FY 99 \\
\end{tabular} & \begin{tabular}{|c} 
Total Circulation \\
FY vo \\
\end{tabular} & \begin{tabular}{|c|} 
Total ILL Recelved \\
FY00 \\
\end{tabular} & $\begin{array}{l}\text { TLL as Sol of } \\
\text { Total Cire } \\
\text { FY, ion }\end{array}$ \\
\hline Amherst & 514799 & 951 & $0.18 \%$ & 501725 & 1219 & $0.24 \%$ \\
\hline Auburn & 199170 & 467 & $0.23 \%$ & 198728 & 453 & $0.23 \%$ \\
\hline Belchertown & 148051 & 2341 & $1.58 \%$ & 125424 & 1869 & $1.49 \%$ \\
\hline Bellingham & 93412 & 470 & $0.50 \%$ & 98004 & 417 & $0.43 \%$ \\
\hline Dudley & 60064 & 484 & $0.81 \%$ & 57974 & 493 & $0.85 \%$ \\
\hline Harvard & 66262 & 1397 & $2.11 \%$ & 64255 & 1358 & $2.11 \%$ \\
\hline Holden & 214275 & 1411 & $0.66 \%$ & 224480 & 1806 & $0.80 \%$ \\
\hline Hudson & 128692 & 1082 & $0.84 \%$ & 136458 & 1191 & $0.87 \%$ \\
\hline Marlborough & 207336 & 1350 & $0.65 \%$ & 210268 & 1634 & $0.78 \%$ \\
\hline Miltord & 203508 & 1314 & $0.65 \%$ & 188939 & 1354 & $0.72 \%$ \\
\hline Pittsfield & 284564 & 2161 & $0.76 \%$ & 280269 & 2069 & $0.74 \%$ \\
\hline Shrewsbury & 252549 & 1708 & $0.68 \%$ & 260948 & 1601 & $0.61 \%$ \\
\hline South Hadley & 205812 & 927 & $0.45 \%$ & 155970 & 853 & $0.55 \%$ \\
\hline West Springfield & 207875 & 1045 & $0.50 \%$ & 198547 & 1430 & $0.72 \%$ \\
\hline Westfield & 302734 & 1454 & $0.48 \%$ & 284506 & 1485 & $0.52 \%$ \\
\hline Williamstown & 102598 & 919 & $0.90 \%$ & 96165 & 902 & $0.94 \%$ \\
\hline Totals & 3191701 & 19481 & $0.61 \%$ & 3082660 & 20134 & $0.65 \%$ \\
\hline \multicolumn{7}{|c|}{ z-Test: Two Sample For Means } \\
\hline & $\begin{array}{c}\text { ILL as \% of Total } \\
\text { Circ Frgg }\end{array}$ & $\begin{array}{l}\text { TLL as \% of Total } \\
\text { Circ Fyoo }\end{array}$ & & & & \\
\hline Mean & 0.007486609 & 0.007875161 & & & & \\
\hline Known Variance & $2.31526 \mathrm{E}-05$ & $2.13163 E-05$ & & & & \\
\hline Observations & 16 & 16 & & & & \\
\hline \multicolumn{7}{|l|}{$\begin{array}{l}\text { Hypothesized Mean } \\
\text { Difference }\end{array}$} \\
\hline$z$ & -0.23306655 & & & & & \\
\hline$P(Z<-z)$ one-tail & 0.407854864 & & & & & \\
\hline$z$ Critical one-tall & 1.644853627 & & & & & \\
\hline$P(Z<=z)$ two-tail & 0.815709729 & & & & & \\
\hline 2 Critical two-tal & 1.959963985 & & & & & \\
\hline
\end{tabular}


Table 7. General systemwide holds (adopted 11/00) ILL received as a percentage of total circulation

\begin{tabular}{|c|c|c|c|c|c|c|}
\hline LIBRARIES & $\begin{array}{c}\text { Total Circulation } \\
\text { FY } 00\end{array}$ & \begin{tabular}{|c|} 
Total ILL Recelved \\
FY Do \\
\end{tabular} & \begin{tabular}{|c|} 
ILL as $\%$ of \\
Total Cire \\
FY Coo \\
\end{tabular} & $\begin{array}{l}\text { Total Circulation } \\
\text { FY v1 } \\
\end{array}$ & \begin{tabular}{|c|}
$\begin{array}{c}\text { Total ILL Recelved } \\
\text { FYOI }\end{array}$ \\
\end{tabular} & \begin{tabular}{|c|} 
ILL as \%o \\
Total Cire \\
FY 01 \\
\end{tabular} \\
\hline Amherst & 501725 & 1219 & $0.24 \%$ & 504137 & 8041 & $1.60 \%$ \\
\hline Auburn & 198728 & 453 & $0.23 \%$ & 192087 & 1274 & $0.66 \%$ \\
\hline Belchertown & 125424 & 1869 & $1.49 \%$ & 128084 & 3413 & $2.66 \%$ \\
\hline Bellingham & 98004 & 417 & $0.43 \%$ & 67812 & 610 & $0.90 \%$ \\
\hline Dudley & 57974 & 493 & $0.85 \%$ & 54962 & 1231 & $2.24 \%$ \\
\hline Harvard & 64255 & 1358 & $2.11 \%$ & 64998 & 1578 & $2.43 \%$ \\
\hline Holden & 224480 & 1806 & $0.80 \%$ & 220763 & 2406 & $1.09 \%$ \\
\hline Hudson & 136458 & 1191 & $0.87 \%$ & 136185 & 2441 & $1.79 \%$ \\
\hline Marlborough & 210268 & 1634 & $0.78 \%$ & 202629 & 2803 & $1.36 \%$ \\
\hline Milford & 188939 & 1354 & $0.72 \%$ & 172672 & 2318 & $1.34 \%$ \\
\hline Pittsfield & 280269 & 2069 & $0.74 \%$ & 286814 & 4712 & $1.64 \%$ \\
\hline Shrewsbury & 260948 & 1601 & $0.61 \%$ & 258798 & 3228 & $1.25 \%$ \\
\hline South Hadley & 155970 & 853 & $0.55 \%$ & 149607 & 1577 & $1.05 \%$ \\
\hline West Springfield & 198547 & 1430 & $0.72 \%$ & 198203 & 3114 & $1.57 \%$ \\
\hline Westfield & 284506 & 1485 & $0.52 \%$ & 266151 & 3842 & $1.44 \%$ \\
\hline Williamstown & 96165 & 902 & $0.94 \%$ & 104767 & 3163 & $3.02 \%$ \\
\hline Totals & 3082660 & 20134 & $0.65 \%$ & 3008669 & 45751 & $1.52 \%$ \\
\hline \multicolumn{7}{|c|}{ z-Test: Two Sample For Means } \\
\hline & $\begin{array}{l}\text { TLL as \% of Total } \\
\text { Circ Froo }\end{array}$ & $\begin{array}{l}\text { TLL as \% of lotal } \\
\text { Circ Frot }\end{array}$ & & & & \\
\hline Mean & 0.007875161 & 0.016297485 & & & & \\
\hline Known Variance & $2.13163 E-05$ & 4.30392E-05 & & & & \\
\hline Observations & 16 & 16 & & & & \\
\hline $\begin{array}{l}\text { Hypothesized Mean } \\
\text { Ditterence }\end{array}$ & 0 & & & & & \\
\hline$z$ & -4.199514817 & & & & & \\
\hline$P(Z<-z)$ one-tail & $1.33744 E-05$ & & & & & \\
\hline$z$ Critical one-tail & 1.644853627 & & & & & \\
\hline$P(Z<=z)$ two-tail & $2.67488 E-05$ & & & & & \\
\hline$z$ Critical two-tail & 1.959963985 & & & & & \\
\hline
\end{tabular}

Table 9. OPAC design enhancement: patron-placed Massachusetts virtual catalog holds (adopted 8/04) ILL received as a percentage of total circulation

\begin{tabular}{|c|c|c|c|c|c|c|}
\hline LIBRARIES & \begin{tabular}{|c|}
$\begin{array}{c}\text { Total Circulation } \\
\text { FY } 04\end{array}$ \\
\end{tabular} & \begin{tabular}{|c|} 
Total IILL Recelved \\
FY 04 \\
\end{tabular} & $\begin{array}{l}\text { ILL as \% of } \\
\text { Total Cire } \\
\text { FY'OA }\end{array}$ & $\begin{array}{l}\text { Total Circulation } \\
\text { FY } 05\end{array}$ & \begin{tabular}{|c|}
$\begin{array}{c}\text { Total ILL. Recelved } \\
\text { FYos }\end{array}$ \\
\end{tabular} & $\begin{array}{l}\text { ILL as \% of } \\
\text { Total Cire } \\
\text { Fy'05 } \\
\end{array}$ \\
\hline Amherst & 507103 & 27338 & $5.39 \%$ & 508376 & 34294 & $6.75 \%$ \\
\hline Auburn & 190995 & 8719 & $4.57 \%$ & 195533 & 10561 & $5.40 \%$ \\
\hline Belchertown & 136064 & 9037 & $6.64 \%$ & 144356 & 13131 & $9.10 \%$ \\
\hline Bellingham & 89439 & 4487 & $5.02 \%$ & 80408 & 5441 & $6.77 \%$ \\
\hline Dudley & 48793 & 2809 & $5.76 \%$ & 37700 & 4104 & $10.89 \%$ \\
\hline Harvard & 74198 & 5827 & $7.85 \%$ & 74401 & 7494 & $10.07 \%$ \\
\hline Holden & 294933 & 11969 & $4.06 \%$ & 241037 & 12799 & $5.31 \%$ \\
\hline Hudson & 156393 & 8508 & $5.44 \%$ & 175127 & 11903 & $6.80 \%$ \\
\hline Marlborough & 209168 & 9794 & $4.68 \%$ & 197673 & 12445 & $6.30 \%$ \\
\hline Miltord & 204261 & 9933 & $4.86 \%$ & 181661 & 12077 & $6.65 \%$ \\
\hline Pittsfleid & 280770 & 12191 & $4.34 \%$ & 287578 & 17123 & $5.95 \%$ \\
\hline Shrewsbury & 333712 & 13415 & $4.02 \%$ & 314398 & 18774 & $5.97 \%$ \\
\hline South Hadley & 156502 & 4908 & $3.14 \%$ & 154360 & 7516 & $4.87 \%$ \\
\hline West Springfield & 233697 & 10970 & $4.69 \%$ & 237650 & 14964 & $6.30 \%$ \\
\hline Westfield & 265100 & 7889 & $2.98 \%$ & 278943 & 11104 & $3.98 \%$ \\
\hline Williamstown & 139755 & 8195 & $5.86 \%$ & 143904 & 10374 & $7.21 \%$ \\
\hline Totals & 3320883 & 155969 & $4.70 \%$ & 3253105 & 204104 & $6.27 \%$ \\
\hline \multicolumn{7}{|c|}{ z-Test: Two Sample For Means } \\
\hline & $\begin{array}{l}\text { ILL as \% of fotal } \\
\text { Cire Fro } 4\end{array}$ & $\begin{array}{c}\text { ILL as \% of Total } \\
\text { Circ Fyos }\end{array}$ & & & & \\
\hline Mean & 0.049562682 & 0.067687531 & & & & \\
\hline Known Variance & 0.00015151 & 0.000337456 & & & & \\
\hline $\begin{array}{l}\text { Observations } \\
\text { Hypothesized Mean }\end{array}$ & 16 & 16 & & & & \\
\hline $\begin{array}{l}\text { Hypothesized Mean } \\
\text { Difference }\end{array}$ & 0 & & & & & \\
\hline 2 & -3.278650057 & & & & & \\
\hline$P(Z<-z)$ one-tail & 0.000521524 & & & & & \\
\hline 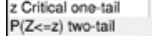 & $\begin{array}{l}1.644853627 \\
0.001043049\end{array}$ & & & & & \\
\hline 2 Critcal two-tail & 1.959963985 & & & & & \\
\hline
\end{tabular}

Table 8. OPAC design enhancement: patron-placed holds (adopted 12/02) ILL received as a percentage of total circulation

\begin{tabular}{|c|c|c|c|c|c|c|}
\hline LIBRARIES & \begin{tabular}{|c|} 
Total Circulation \\
FY 02
\end{tabular} & \begin{tabular}{|c|} 
Total ILL Received \\
FY 02
\end{tabular} & $\begin{array}{c}\text { ILL as \%ol } \\
\text { Total Circ } \\
\text { FY 02 }\end{array}$ & $\begin{array}{l}\text { Total Circulation } \\
\text { FY } 03\end{array}$ & \begin{tabular}{|c} 
Total ILL Received \\
FY03
\end{tabular} & \begin{tabular}{|c|} 
LLL as \% o of \\
Total Circ \\
FY 03
\end{tabular} \\
\hline Amherst & 526855 & 13614 & $2.58 \%$ & 547139 & 18277 & $3.34 \%$ \\
\hline Auburn & 189169 & 2799 & $1.48 \%$ & 182029 & 4504 & $2.47 \%$ \\
\hline Belchertown & 130562 & 5252 & $4.02 \%$ & 134183 & 6511 & $4.85 \%$ \\
\hline Bellingham & 67667 & 1259 & $1.86 \%$ & 76067 & 2546 & $3.35 \%$ \\
\hline Dudley & 55500 & 1281 & $2.31 \%$ & 54478 & 1585 & $2.91 \%$ \\
\hline Harvard & 68125 & 3418 & $5.02 \%$ & 72339 & 4135 & $5.72 \%$ \\
\hline Holden & 248615 & 4802 & $1.93 \%$ & 278296 & 6215 & $2.23 \%$ \\
\hline Hudson & 142075 & 4828 & $3.40 \%$ & 156275 & 5755 & $3.68 \%$ \\
\hline Marlborough & 191491 & 4522 & $2.36 \%$ & 201183 & 5855 & $2.91 \%$ \\
\hline Milford & 180012 & 5850 & $3.25 \%$ & 183803 & 7610 & $4.14 \%$ \\
\hline Pittsfield & 301878 & 6944 & $2.30 \%$ & 297840 & 7594 & $2.55 \%$ \\
\hline Shrewsbury & 266159 & 5358 & $2.01 \%$ & 297744 & 7198 & $2.42 \%$ \\
\hline South Hadley & 156855 & 2588 & $1.65 \%$ & 157005 & 3187 & $2.03 \%$ \\
\hline West Springfield & 214549 & 5680 & $2.65 \%$ & 220851 & 7091 & $3.21 \%$ \\
\hline Westtield & 283032 & 5726 & $2.02 \%$ & 283039 & 5240 & $1.85 \%$ \\
\hline Williamstown & 121875 & 5352 & $4.39 \%$ & 133537 & 6251 & $4.68 \%$ \\
\hline Totals & 3144419 & 79273 & $2.52 \%$ & 3275808 & 99654 & $3.04 \%$ \\
\hline \multicolumn{7}{|c|}{ z-Test: Two Sample For Means } \\
\hline & $\begin{array}{l}\text { TLL as \% of Total } \\
\text { Circ Fro2 }\end{array}$ & $\begin{array}{l}\text { RLL as \% of Total } \\
\text { Circ Fro3 }\end{array}$ & & & & \\
\hline Mean & 0.02702395 & 0.032716534 & & & & \\
\hline Known Variance & 0.000106872 & 0.000121227 & & & & \\
\hline Observations & 16 & 16 & & & & \\
\hline \multicolumn{7}{|l|}{ Hypothesized Mean } \\
\hline$z$ & -1.507675145 & & & & & \\
\hline $\mathrm{P}(\mathrm{Z}<=\mathrm{Z})$ one-tal & 0.065818845 & & & & & \\
\hline$z$ Critical one-tall & 1.644853627 & & & & & \\
\hline$P\left(Z_{<}=z\right)$ two-tail & 0.13163769 & & & & & \\
\hline$z$ Critical two-tail & 1.959963985 & & & & & \\
\hline
\end{tabular}

Table 10. OPAC design enhancements: "Cumulative Effect" (FY '02 to $F Y$ '05) ILL received as a percentage of total circulation

\begin{tabular}{|c|c|c|c|c|c|c|}
\hline LIBRARIES & \begin{tabular}{|c|}
$\begin{array}{c}\text { Total Circulation } \\
\text { FY } 02\end{array}$ \\
\end{tabular} & \begin{tabular}{|c|} 
Total ILL Received \\
FY 02 \\
\end{tabular} & 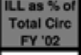 & \begin{tabular}{|c|}
$\begin{array}{c}\text { Total Circulation } \\
\text { FY 05 }\end{array}$ \\
\end{tabular} & \begin{tabular}{|c|}
$\begin{array}{c}\text { Total ILL Recelved } \\
\text { Fro5 }\end{array}$ \\
\end{tabular} & $\begin{array}{c}\text { |LL as \% of } \\
\text { Total Cire } \\
\text { FY } 05 \\
\end{array}$ \\
\hline Amherst & 526855 & 13614 & $2.58 \%$ & 508376 & 34294 & $6.75 \%$ \\
\hline Auburn & 189169 & 2799 & $1.48 \%$ & 195533 & 10561 & $5.40 \%$ \\
\hline Belchertown & 130562 & 5252 & $4.02 \%$ & 144356 & 13131 & $9.10 \%$ \\
\hline Bellingham & 67667 & 1259 & $1.86 \%$ & 80408 & 5441 & $6.77 \%$ \\
\hline Dudley & 55500 & 1281 & $2.31 \%$ & 37700 & 4104 & $10.89 \%$ \\
\hline Harvard & 68125 & 3418 & $5.02 \%$ & 74401 & 7494 & $10.07 \%$ \\
\hline Holden & 248615 & 4802 & $1.93 \%$ & 241037 & 12799 & $5.31 \%$ \\
\hline Hudson & 142075 & 4828 & $3.40 \%$ & 175127 & 11903 & $6.80 \%$ \\
\hline Marlborough & 191491 & 4522 & $2.36 \%$ & 197673 & 12445 & $6.30 \%$ \\
\hline Milford & 180012 & 5850 & $3.25 \%$ & 181661 & 12077 & $6.65 \%$ \\
\hline Pittsfield & 301878 & 6944 & $2.30 \%$ & 287578 & 17123 & $5.95 \%$ \\
\hline Shrewsbury & 266159 & 5358 & $2.01 \%$ & 314398 & 18774 & $5.97 \%$ \\
\hline South Hadley & 156855 & 2588 & $1.65 \%$ & 154360 & 7516 & $4.87 \%$ \\
\hline West Springfield & 214549 & 5680 & $2.65 \%$ & 237650 & 14964 & $6.30 \%$ \\
\hline Westfield & 283032 & 5726 & $2.02 \%$ & 278943 & 11104 & $3.98 \%$ \\
\hline Williamstown & 121875 & 5352 & $4.39 \%$ & 143904 & 10374 & $7.21 \%$ \\
\hline Totals & 3144419 & 79273 & $2.52 \%$ & 3253105 & 204104 & $6.27 \%$ \\
\hline \multicolumn{7}{|c|}{ z-Test: Two Sample For Means } \\
\hline & $\begin{array}{l}\text { ILL as \% of Total } \\
\text { Cire Fro2 }\end{array}$ & $\begin{array}{l}\text { IIL. as \% of Total } \\
\text { Circ Fros }\end{array}$ & & & & \\
\hline Moan & 0.02702395 & 0.067687531 & & & & \\
\hline Known Variance & 0.000106872 & 0.000337456 & & & & \\
\hline Observations & 16 & 16 & & & & \\
\hline $\begin{array}{l}\text { Hypothesized Mean } \\
\text { Difference }\end{array}$ & 0 & & & & & \\
\hline$z$ & .7 .71638296 & & & & & \\
\hline$P(Z<=z)$ one-tail & $5.9952 \mathrm{E}-15$ & & & & & \\
\hline$z$ Critical one-tail & 1.644853627 & & & & & \\
\hline$P(Z<=z)$ two-tail & $1.19904 \mathrm{E}-14$ & & & & & \\
\hline 2 Critical two-tal & 1.959963985 & & & & & \\
\hline
\end{tabular}




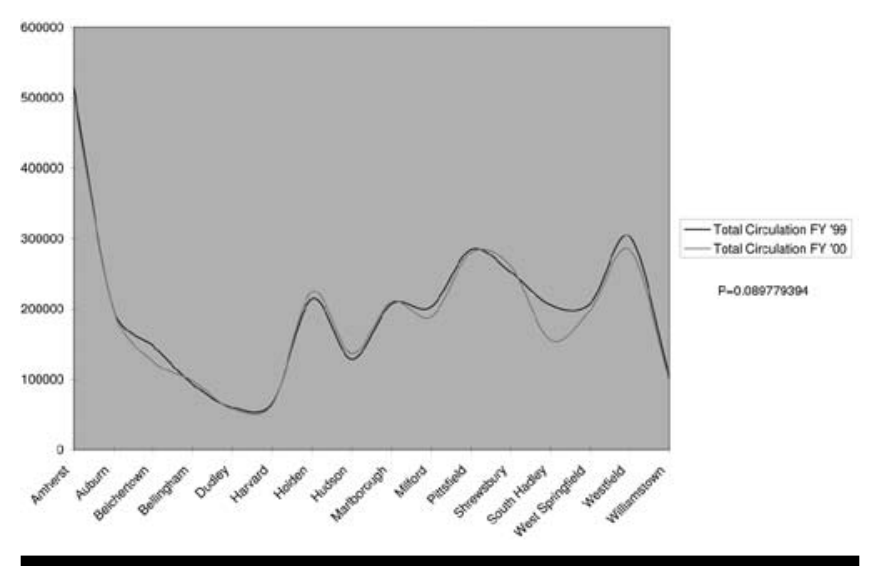

Chart 1. Circulation comparison prior to any ILL OPAC enhancement (FY'99 to FY '00)

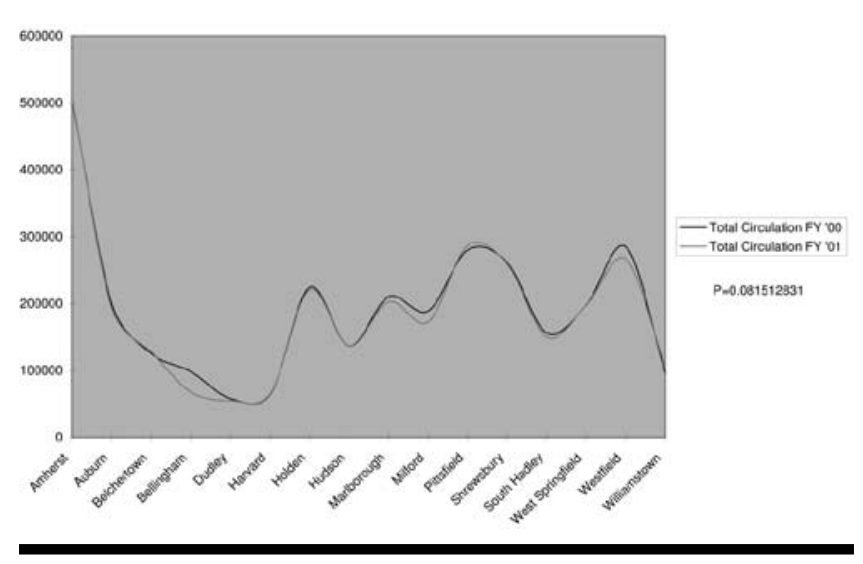

Chart 3. Circulation comparison before and after general systemwide holds implementation (adopted 11/00)

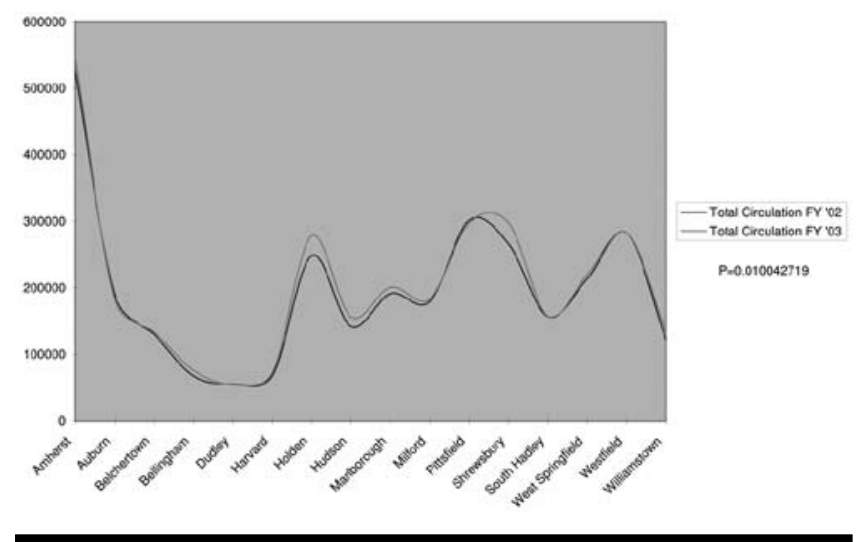

Chart 5. Circulation comparison before and after patron-placed holds OPAC enhancement (adopted 12/02)

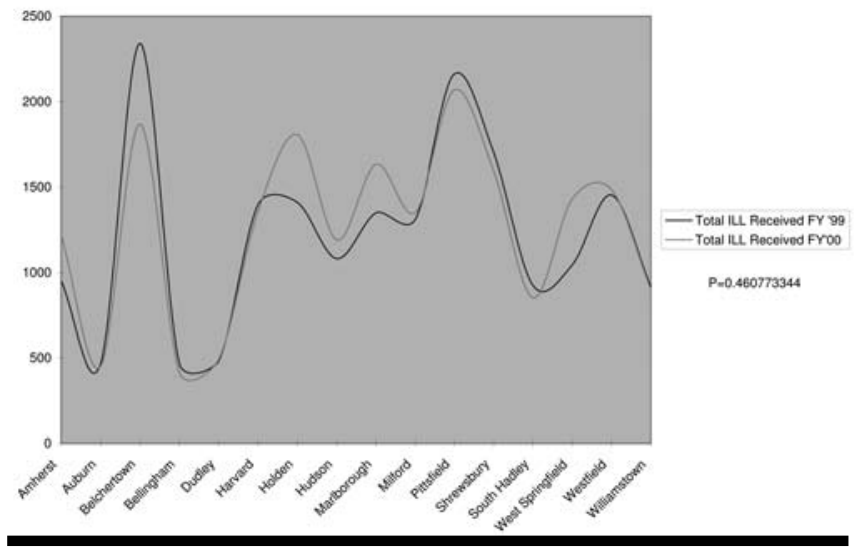

Chart 2. ILL received comparison prior to any ILL OPAC enhancement (FY' 99 to $\mathrm{FY}$ '00

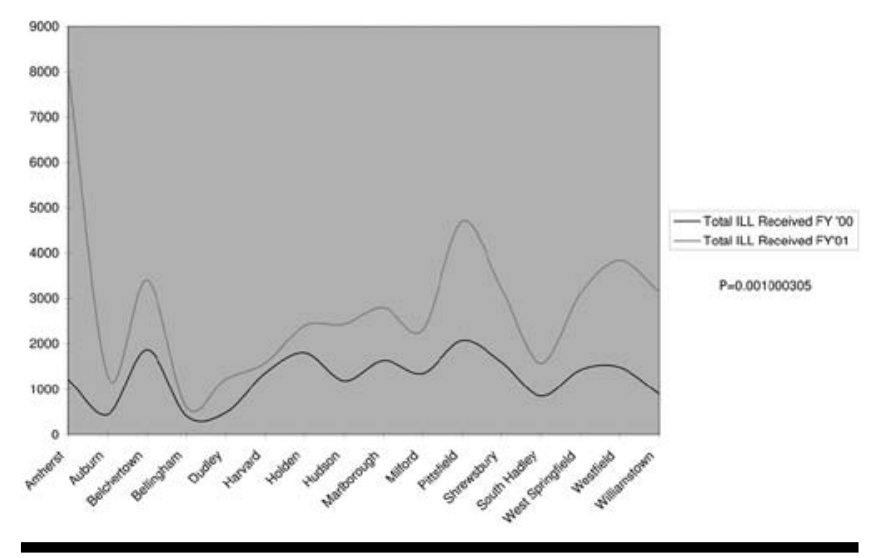

Chart 4. Holds received comparison before and after general systemwide holds implementation (adopted 11/00)

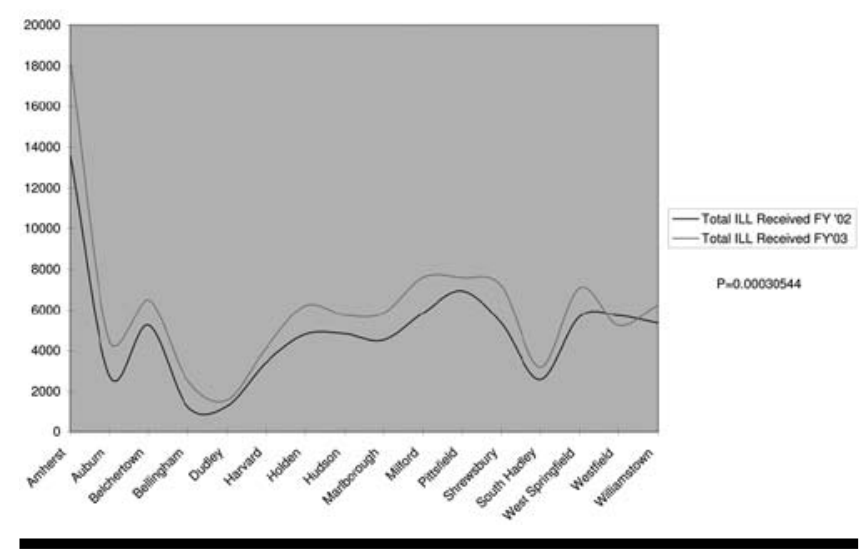

Chart 6. Holds received comparison before and after patron-placed holds OPAC enhancement (adopted 12/02) 


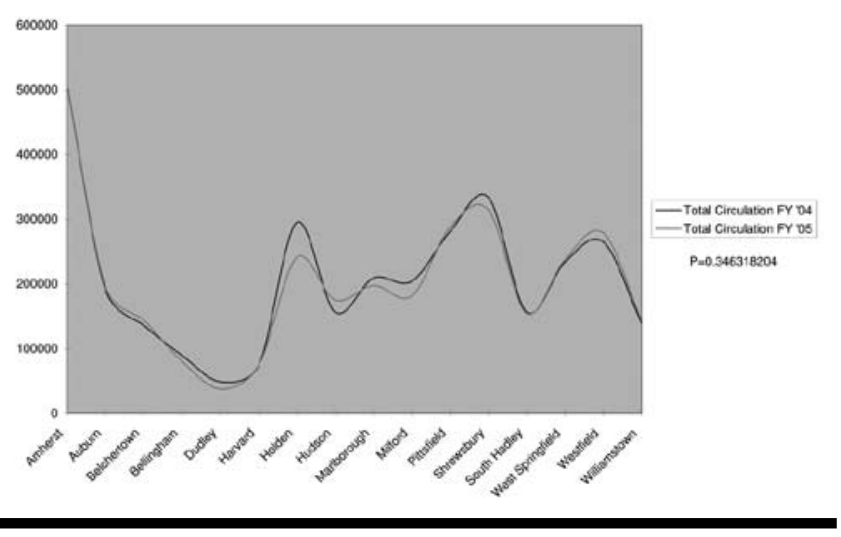

Chart 7. Circulation comparison before and after Massachusetts virtual catalog OPAC enhancement (adopted 8/04)

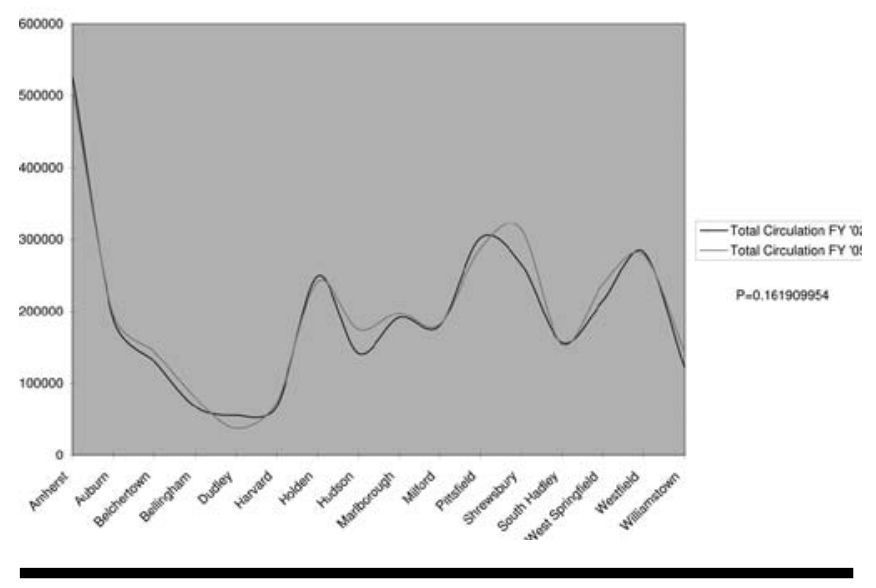

Chart 9. Circulation comparison OPAC enhancements "Cumulative Effect" (FY '02 to FY '05)

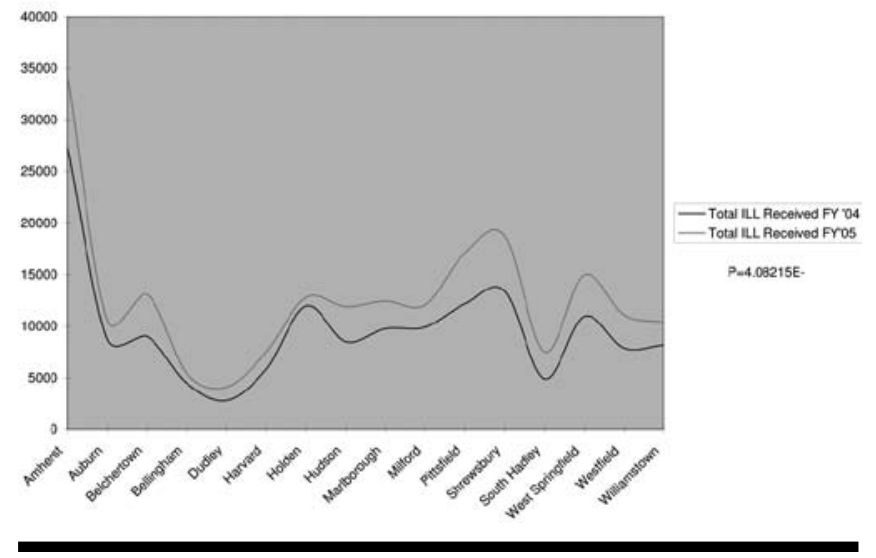

Chart 8. Holds received comparison before and after Massachusetts virtual catalog OPAC enhancement (adopted 8/04)

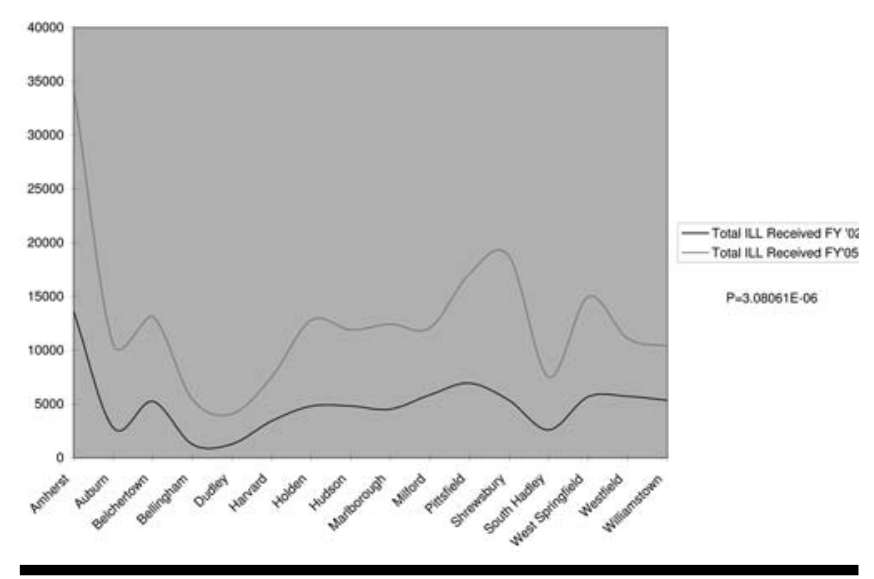

Chart 10. ILL comparison OPAC enhancements "Cumulative Effect" (FY '02 to FY '05)

\section{Index to Advertisers}

